\title{
Desain dan Pembuatan Papan Tiruan dari Bahan Komposit Laminate Diperkuat Lembaran Batang Pisang
}

\section{Design and Manufacture of Artificial Boards From Laminate Composite Materials Reinforced by Banana Stem Sheets}

\author{
Frawito T.S. Sihombing ${ }^{1 *}$, Christoper Hutasoit ${ }^{2}$, Trio Ismanto Padang ${ }^{3}$ \\ 1,2,3 Jurusan Teknik Mesin, Fakultas Teknologi Industri, Institut teknologi Medan, Indonesia \\ Diterima: 03-08-2020 ; Disetujui: 14-02-2021 ; Diterbitkan: 06-05-2021 \\ *Corresponding author: sihombingfrawito55@gmail.com
}

\begin{abstract}
Abstrak
Pada saat ini, pemanfaatan bahan-bahan limbah pertanian yang ramah lingkungan dan mudah terurai di alam menjadi perioritas utama pengembangan bahan-bahan alternatif untuk rekayasa teknik. Wilayah Indonesia merupakan penghasil produk pisang yang terbesar dan berpotensi menghasilkan limbah batang pisang yang melimpah dalam setiap panennya. Dalam studi ini, penyelidikan bertujuan untuk mendesain papan tiruan dari limbah batang pisang, mencetaknya menjadi papan tiruan, dan menguji kekuatan mekaniknya. Desain produk berdasarkan ketebalan papan komersial ialah $50 \mathrm{~mm}$. Pembuatan papan tiruan dengan menggunakan alat cetakan khusus metode tekan. Pengujian kekuatan lentur menggunakan alat uji Universal Testing Machine dengan metode bending tiga titik. Hasilnya diperoleh papan tiruan yang mengalami penambahan ketebalan 10\% dari tebal awal yang disebabkan karakteristik batang pisang yang memiliki rongga udara. Apabila dibandingkan dengan papan komersial, papan tiruan yang dihasilkan memiliki kemampuan peredaman yang cukup baik terhadap beban yang diberikan sehingga perlu penyelidikan lebih lanjut untuk pengembangan bahan ini menghasilkan kualitas papan yang lebih baik.
\end{abstract}

Kata Kunci: Papan tiruan, batang pisang, komposit laminat

\begin{abstract}
At present, the use of agricultural waste materials that are environmentally friendly and easily biodegradable in nature is a major priority in developing alternative materials for engineering. Indonesia is the largest producer of banana products and has the potential to produce abundant banana stem waste in every harvest. In this study, the objective of the investigation was to design artificial boards from waste banana stalks, print them into dummy boards, and test their mechanical strength. The product design is based on a commercial board thickness of $50 \mathrm{~mm}$. Making artificial boards using a special molding method using the press method. Testing of flexural strength using the Universal Testing Machine with the threepoint bending method. The result is that the artificial board has an additional thickness of 10\% from the initial thickness due to the characteristic of banana stems which have air cavities. When compared with commercial boards, the resulting artificial board has a fairly good damping ability against a given load so that further investigation is needed for the development of this material to produce a better board quality. Keywords: Artificial board, banana stem, laminate composite
\end{abstract}

How to Cite: Sihombing, F.T.S. 2021, Tahun, Desain dan Pembuatan Papan Tiruan dari Bahan Komposit Laminate Diperkuat Lembaran Batang Pisang, JMEMME (Journal of Mechanical Engineering, Manufactures, Materials and Energy), Vol 5 (1): 1-7 
Frawito T.S. Sihombing, , Desain dan Pembuatan Papan Tiruan dari Bahan Komposit ...

\section{PENDAHULUAN}

Di Indonesia, kebutuhan bahan baku kayu untuk industri kehutanan saat ini telah melampaui kemampuan sumber daya alam dalam memperoduksi kayu secara lestari, apalagi pertumbuhan industri kayu yang semakin meningkat jumlahnya, sehingga terjadi defisi kayu untuk industri. Hal ini berkaitan dengan peningkatan jumlah penduduk yang ada di Indonesia, sehingga keperluan kayu semakin meningkat. Pada tahun 2013, kebutuhan log nasional tercata hingga mencapai 49 juta m3. Kebutuhan itu dipenuhi dari hutan alam sebesar 4 juta m3, perhutani sebesar 922,123 m3, hutan tanaman industri sebanyak 21 juta m3. Untuk sisa kebtuhan kayu tersebut dipenuhi dari hutan rakyat dengan suplai sebanyak 23 juta $\mathrm{m} 3$ [1].

Hutan rakyat merupakan salah satu alternatif untuk mengatasi kekurangan kebutuhan kayu sekarang dan di masa depan tentunya. Pengembangan hutan rakyat di arahkan untuk mengembalikan produktivitas lahan kritis [2]. Konservasi lahan, perlindungan hutan, pengentasan kemiskinan melalui pemberdayaan masyarakat. Pembangunan hutan rakyat di Indonesia tahun 2012 sebesar 1.119 .937 ha [3]. Data Directorat Jendral Rehabilitasi Lahan dan Perhutanan Sosial (2006) menyebutkan bahwa luas total hutan rakyat di seluruh Indonesia sebesar 1.272.505.61 ha dan meningkat sesuai Data Direktorat Jendral Rehabilitasi Lahan dan Perhutanan Sosial (2009) menjadi 3.589.343 ha, dimana 77,98 \% atau 2.779.181 ha terdapat dipulau jawa. Peningkatan juga terjadi pada luas hutan rakyat Jawa Tengah dari tahun 2010 sebesar 329.943 ha menjadi 749.923 ha pada tahun 2012 [4].

Peluang pengembangan komuditas pisang masih terbuka luas. Keberhasilan usaha tani pisang dapat dilakukan dengan penerapan teknologi, penggunaan varietas unggul dan peerbaikan varietas harus dilaksanakan [5]. Varietas unggul yang dimksud adalah varietas yang toleran atau tahan terhadap hama dan penyakit, mampu berproduksi tinggi,serta mempunyai kualitas buah yang bagus serta disukai masyarakat luas [6]. Selain itu, pembudidayaan pohon pisang menghasilkan limbah dari batang pisang tersebut ternyata juga dapat digunakan sebagai alternative sebagai pengganti kertas dan masih ada lagi lainnya [7].

Produksi pisang di Indonesia cukup besar bahkan Indonesia menjadi salah satu penghasil pisang terbesar di dunia [8]. Berdasarkan angkat tetap (ATAP) tahun 2013 produksi pisang mencapai 6,218 juta ton. Untuk wilayh Asia, Indonesia juga termasuk penghasil pisang terbesar karena $50 \%$ produksi pisang di asia dihasilkan oleh Indonesia [9]. Hampir seluruh wilayah Indonesia merupakan daerah penghasil pisang karena didukung oleh iklim yang sesuai. Pengembangan dan persebaran pisang dipengaruhi oleh beberapa faktor, antara lain iklim, media tanam dan ketinggian tempat. Namun demikian 90\% produksi pisang masih digunakan untuk konsumsi dalm negeri, sedang kan untuk ekspor hanya $10 \%$ [10].

Bahan komposit adalah bahan yang dibentuk oleh dua atau lebih bahan penyusun yang memiliki perbedaan fasa [11]. Bahan ini memiliki karakteristik bahan-bahan penyusunnya dengan perbaikan terhadap sifat-sifat mekaniknya. Bahan ini dapat menjadi 
bahan alternatif pengganti bahan berbasis logam karena memiliki sifat yang ringan, elastisi tinggi, dan tahan korosi.

Isu kerusakan lingkungan hidup menyebabkan usaha pencarian bahan-bahan yang ramah lingkungan yang tidak merusak lingkungan hidup dan mudah terurai di alam. Serat alami menjadi bahan alternatif yang dipilih dan terus dikembangkan. Penyelidikanpenyelidikan tentang bahan-bahan ini telah dikerjakan dan dilaporkan. Penyelidikanpenyelidikan tersebut antara lain: pembuatan bahan busa dari serat tandan kosong kelapa sawit [12], pembuatan papan skateboard dari batang pisang [13], pembuatan pipa air dari arang kayu [14], pembuatan pipa air dari kulit kerang [15], dll. Selain itu, penyelidikan bahan-bahan ini juga termasuk analisa kekuatannya secara numerical berdasarkan hasil eskperimen sehingga diperoleh kondisi pembebanan secara detail [16] [17] [18] [19]. Penelitian ini juga mengacu pada pengujian-pengujian terdahulu yang dilakukan untuk mendapatkan bahan-bahan alami lain yang memiliki kemungkinan untuk dipergunakan lebih lanjut [20] [21].

Berdasarkan data-data diatas tersebut, penulis melakukan penyelidikan dalam aplikasi bahan ini untuk pembuatan papan tiruan dari pelepah batang pisang kepok. Tujuan Khusus Penelitian ini adalah mendesain papan tiruan dan pembuatan papan tiruan dari bahan komposit Laminat batang pisang kapok dan analisa kekuatan lenturnya.

\section{METODE PENELITIAN}

Penelitian ini dilaksanakan di laboratorium Produksi, Institut teknologi Medan. Bahan yang dipergunakan antara lain pelepah batang pisang kapok yang diambil dari Koperasi Petani Pisang Kecamatan Sunggal, Kabupaten Deli Serdang, Sumatera Utara, Indonesia. $\mathrm{NaOH} 1 \mathrm{M}$ dibeli dari PT. Justus Kimiaraya, Medan, Indonesia. Polyvinyl Acetat (PA) dibeli dari PT. Bio Industries, Jawa Timur, Indonesia. Alat yang dipergunakan antara lain alat cetak papan tiruan, alat pencacah batang pisang, sarung tangan, wadah penampung, timbangan, dan kuas/roller untuk meratakan PA pada batang pisang.

Prosedur pembuatan papan tiruan diawali dengan pencacahan batang pisang menjadi ukuran panjang x lebar ialah 600 x $50 \mathrm{~mm}$. Selanjutnya, cacahan tersebut direndam dalam air selama 24 jam. Setelah itu, cacahan kembali direndam dalam air larutan $\mathrm{NaOH} 1 \mathrm{M}$ sebanyak $1 \%$ selama 24 jam untuk menghilangkan getah pisang. Proses selanjutnya, cacahan batang pisang dikeringkan secara alami selama 7 hari dan perubahan berat cacahan tersebut diukur dan dicatat. Apabila berat cacahan kering telah stabil, maka sudah bisa digunakan untuk pencetakan kayu papan tiruan.

Proses pencetakan papan tiruan diawali dengan penyusunan cacahan kering pada luas media cetakan 300 x 150 × 50 mm. Pada masing-masing lapisan diberikan PA sebagai pengikat. Selanjutnya susunan tersebut ditekan dan dibiarkan selama 24 jam. 
Frawito T.S. Sihombing, , Desain dan Pembuatan Papan Tiruan dari Bahan Komposit ...

\section{HASIL DAN PEMBAHASAN}

Produk papan tiruan yang dihasilkan berukuran 300 x 150 x $50 \mathrm{~mm}$. Setelah cetakan dibuka, produk ini mengalami pengembangan sehingga terjadi penambahan ukuran ketebalan $10 \%$ dari tebal awal. Hal ini disebab batang pisang kering memiliki pori-pori yang mampu diisi oleh udara. Bentuk papan tiruan dari komposit laminate diperkuat lembaran batang pisang diperlihatkan pada gambar 1 .

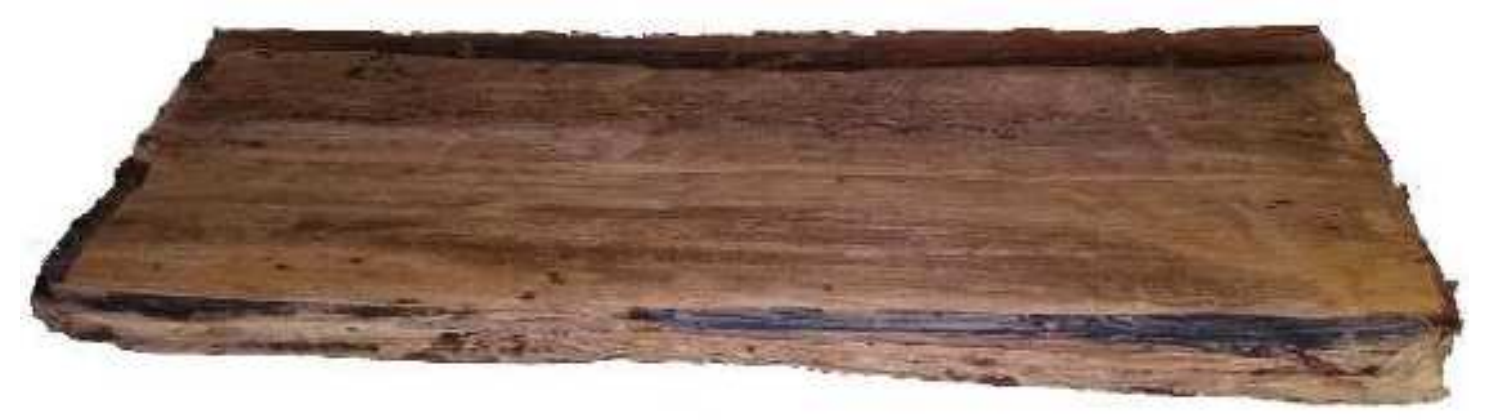

Gambar 1. Papan tiruan dari komposit laminat

Hasil pengujian kekuatan lentur papan tiruan menggunakan metode uji lentur tiga titik [18]. Hasil pengujian ini selanjutnya dibandingkan dengan kekuatan lentur kayu komersial. Grafik hasil pengujian lentur papan tiruan dan komersial diperlihatkan pada gambar 2 dan 3 secara berturut-turut.

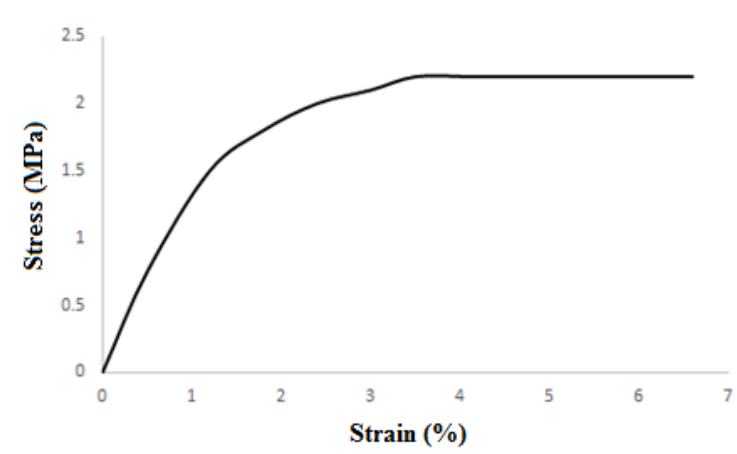

(a)

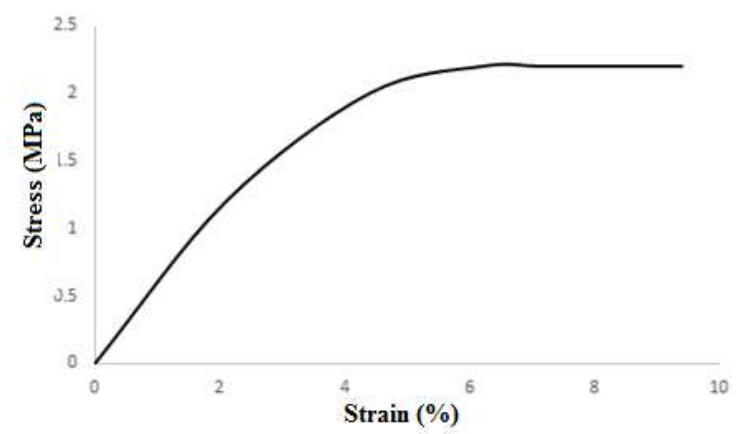

(c)

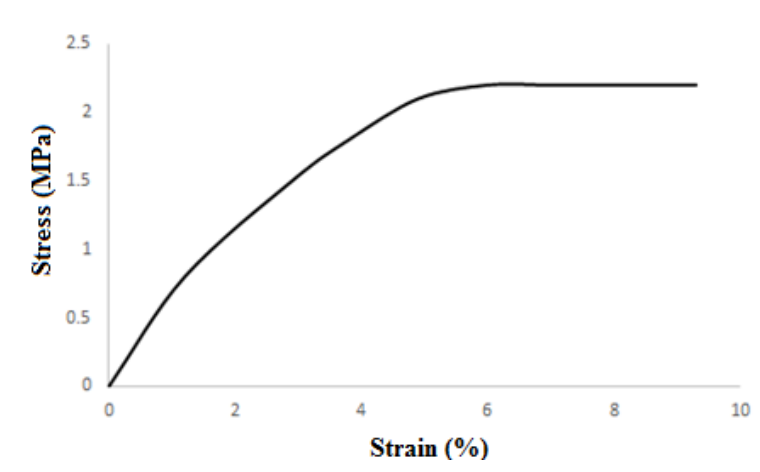

(b)

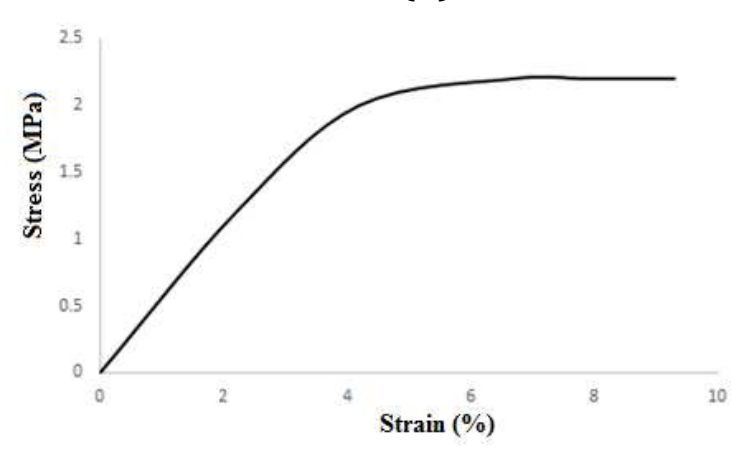

(d)

Gambar 2. Grafik uji lentur papan tiruan: (a) uji pertama, (b) uji kedua, (c) uji ketiga, dan (d) uji keempat 


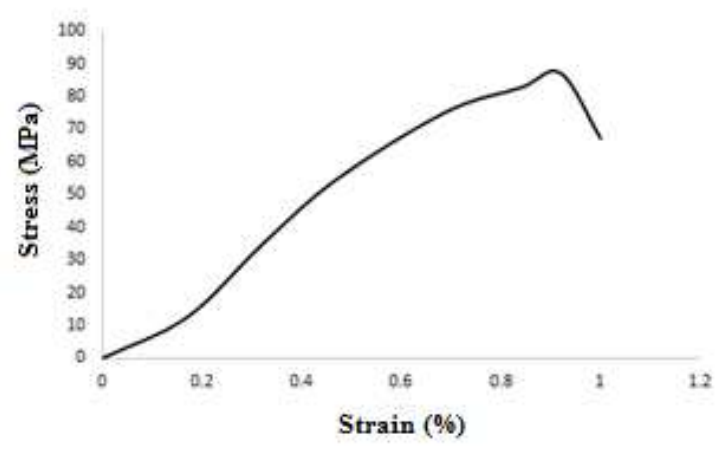

(a)

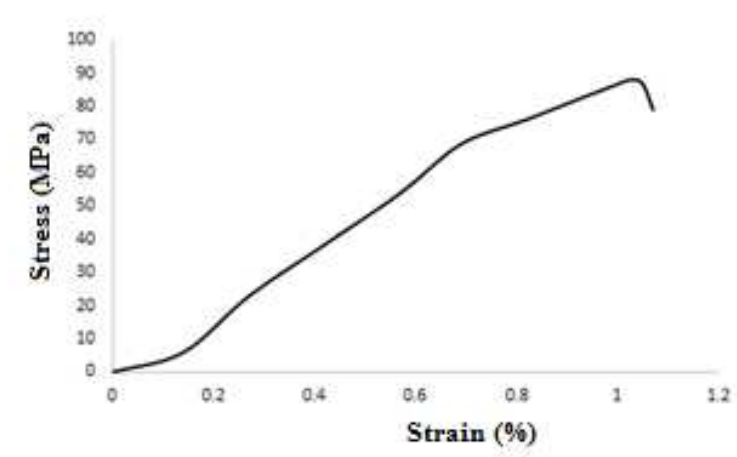

(c)

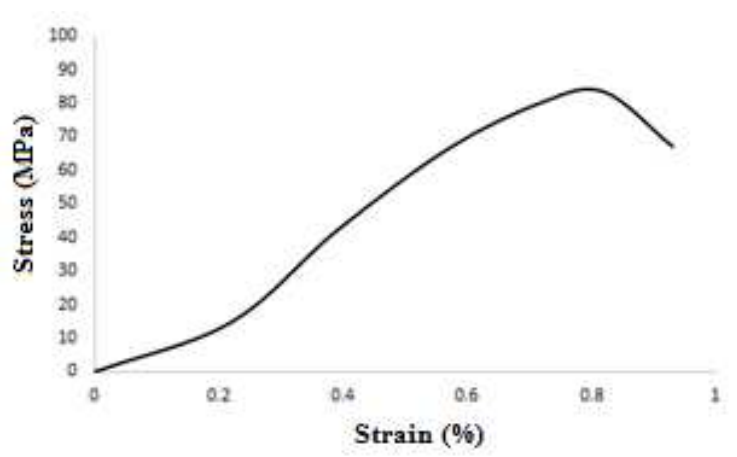

(b)

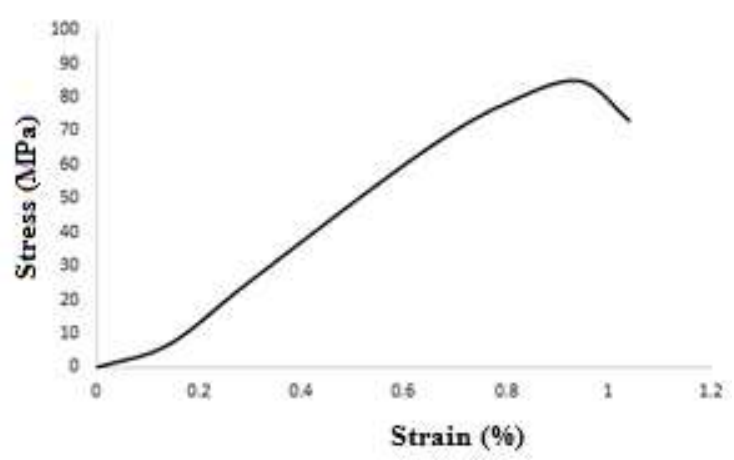

(d)

Gambar 3. Grafik uji lentur papan komersial: (a) uji pertama, (b) uji kedua, (c) uji ketiga, dan (d) uji keempat

Berdasarkan hasil uji tersebut, kekuatan lentur papan tiruan masil lebih kecil dibandingkan dengan papan komersial. Dalam tiga kali pengujian tersebut, kekuatan lentur papan tiruan jauh dibawah papan komersial. Akan tetapi, berdasarkan hasil pengamatan pada uji lentur tersebut papan tiruan mampu menahan beban lentur tanpa menunjukkan kepatahan (gambar 4). Sedangkan pada papn komersial, bentuk kepatahan terlihat jelas.

Dengan demikian, papan tiruan dari bahan komposit laminat ini memiliki potensi untuk dikembangkan lebih lanjut. Lebih lanjut, papan tiruan ini memiliki kemampuan peredaman yang baik terhadap beban yang diberikan, tidak mudah rusak, dan memiliki sifat elastis yang tinggi. 


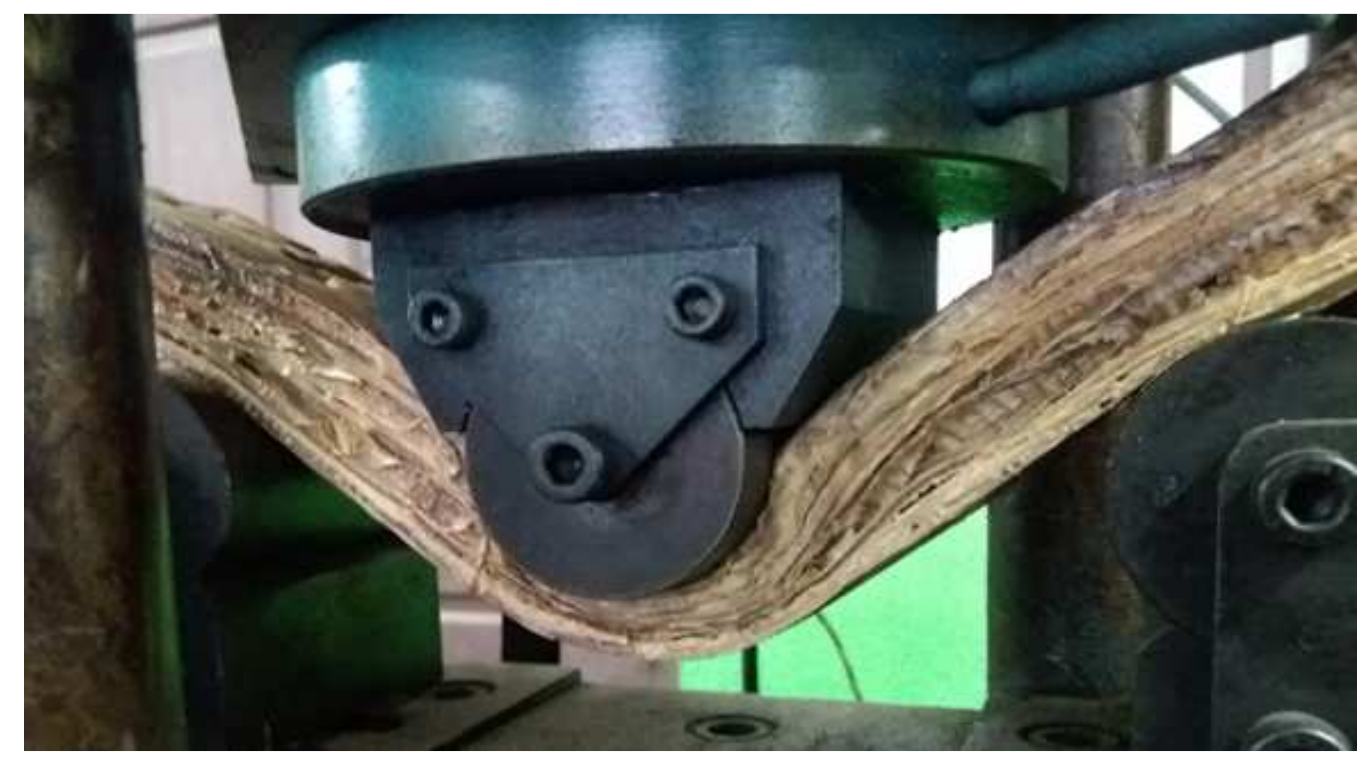

Gambar 4. Pengujian lentur pada papan tiruan

\section{KESIMPULAN}

Papan tiruan dari bahan komposit laminat diperkuat lembaran batang pisang telah berhasil dikerjakan dalam bentuk skala laboratorium. Papan yang dihasilkan ini mengalami pengembangan pada arah tebalnya dengan pertambahan tebal sekitar $10 \%$. Hasil uji kekuatan lentur menunjukkan papan tiruan ini memiliki performa yang lebih baik dibandingkan dengan papan komersial. Papan ini mampu meredam beban yang diberikan dan tidak menunjukkan bentuk kepatahan hingga batas maksimum pengujian.

\section{UCAPAN TERIMAKASIH}

Penghargaan dan terima kasih kepada Bapak Zulfikar, ST. MT. yang telah membimbing tim selama penelitian berlangsung. Penelitian ini juga didukung sepenuhnya oleh Jurusan Teknik Mesin, Fakultas Teknologi Industri, Institut Teknologi Medan.

\section{REFERENSI}

[1] Y. Rahayu, Statistik Bidang Planologi Kehutanan dan Tata Lingkungan Tahun 2016, Jakarta: Kementrian Pertanian Republik Indonesia, 2017.

[2] A. R. H. Bisjoe, A. K. Wakka and N. Hayati, Kemitraan Pengelolaan Hutan Rakyat: Pembelajaran dari Bulukumba, Makassar: Kementrian Kehutanan Republik Indonesia, 2016.

[3] T. Puspitojati, M. Y. Mile and E. Fauziah, Hutan Rakyat Sumbangsih Masyarakat Pedesaan Untuk Hutan Tanaman, Jakarta: PT. Kanisius, 2014. 
[4] A. Rakatama and R. Pandit, "Forest Policy and Economics Reviewing social forestry schemes in Indonesia : Opportunities and challenges," Forestry Policy Economics Journal, vol. 111, no. 1, p. 1-13, 2020.

[5] Y. Yamamoto, Y. Shigetomi, Y. Ishimura and M. Hattori, "Forest change and agricultural productivity : Evidence from Indonesia," World Dev Journal, vol. 114, p. 196-207, 2019.

[6] C. Bigot, C. Bugaud and J. Camilo, "Impact of farming type, variety and geographical origin on bananas bacterial community," Food Control Journal, vol. 109, pp. 1-8, 2019.

[7] T. Ahmad and M. Danish, "Prospects of banana waste utilization in wastewater treatment : A review," Journal of Environment Management, vol. 206, p. 330-348, 2018.

[8] S. Bhushan, M. S. Rana and N. Nandan, "Energy harnessing from banana plant wastes : A review," Bioresource Technology Reports Journal, vol. 7, p. 1-12, 2019.

[9] D. Chrisendo, V. V. Krishna and H. Siregar, "Land-use change, nutrition , and gender roles in Indonesian farm households," Forest Policy and Economics Journal, vol. 118, p. 1-11, 2019.

[10] B. Harpini, Komoditas Ekspor Indonesia, Jakarta: Kementerian Pertanian Republik Indonesia, 2017.

[11] M. K. Egbo, "A fundamental review on composite materials and some of their applications in biomedical engineering," Journal of King Saud University, vol. 20, p. 1-19, 2020.

[12] A. J. Zulfikar and M. Y. R. Siahaan, "Investigation of Mechanical Behavior of Polymeric Foam Materials Reinforced by Oil Palm Empty Fruit Bunches (OPEFB) Fibers Due to Static and Dynamic Loads," JOURNAL OF MECHANICAL ENGINEERING MANUFACTURES MATERIALS AND ENERGY, vol. 3, no. 1, pp. 10-19, 2019.

[13] A. J. Zulfikar and M. Y. R. Siahaan, "Design and manufacture of skateboard from banana stem," JOURNAL OF MECHANICAL ENGINEERING MANUFACTURES MATERIALS AND ENERGY, vol. 3, no. 2, pp. 109-116, 2019.

[14] A. J. Zulfikar, "Desain Cetakan Pipa Air Komposit Polimer Arang Kayu," in Seminar Nasional Teknologi dan Rekayasa, Tapak Tuan, 2016.

[15] A. Rahmansyah and A. Zulfikar, "Manufacture of Water Pipe From Clampshell Powder Materials," JMEMME (JOURNAL OF MECHANICAL ENGINEERING, MANUFACTURES, MATERIALS AND ENERGY), vol. 2, no. 2, pp. 73-77, 2018.

[16] A. J. Zulfikar, "The Flexural Strength of Artificial Laminate Composite Boards made from Banana Stems," Budapest International Research in Exact Sciences (BirEx) Journal, vol. 2, no. 3, pp. 334-340, 2020.

[17] A. J. Zulfikar and Z. Arief, "Kekuatan Tekan Parking Bumper Trapesium Dimodifikasi (PBTD) Berbahan Serat Tandan Kosong Kelapa Sawit," Mekintek, vol. 6, no. 2, pp. 423-428, 2015.

[18] A. J. Zulfikar, A. Syofyan and M. Y. R. Siahaan, "Numerical Simulation on The Onion Dryer Frame Capacity of $5 \mathrm{~kg} / \mathrm{hour}, "$ JMEMME (JOURNAL OF MECHANICAL ENGINEERING, MANUFACTURES, MATERIALS AND ENERGY), vol. 2, no. 2, pp. 86-92, 2018.

[19] A. J. Zulfikar, "ANALISA KEKUATAN STATIK TARIK KOMPOSIT PF DIPERKUAT SERAT TKKS DENGAN SIMULASI NUMERIK ANSYS 9.o," Meintek, vol. 2, no. 1, pp. 95-98, 2011.

[20] A. J. Zulfikar, "ANALISA KEKUATAN STATIK TARIK MATERIAL KOMPOSIT POLIMER SERAT BUAH PINANG DENGAN PERLAKUAN PERENDAMAN LARUTAN NaOH 1 M 1\%," Mekintek, vol. 3, no. 2, pp. 224-227, 2012.

[21] M. Yuhazri, A. Zulfikar and A. Ginting, "Fiber Reinforced Polymer Composite as a Strengthening of Concrete Structures: A Review," in International Conference in Industry and Manufacture Engineering, Medan, 2020. 